This is an electronic reprint of the original article. This reprint may differ from the original in pagination and typographic detail.

Author(s): Lähteenmäki, Mika; Pöyhönen, Sari

Title: $\quad$ Language Rights of the Russian-Speaking Minority in Finland: Multi-sited Historical Arguments and Language Ideologies

Year: $\quad 2015$

Version:

Please cite the original version:

Lähteenmäki, M., \& Pöyhönen, S. (2015). Language Rights of the Russian-Speaking Minority in Finland: Multi-sited Historical Arguments and Language Ideologies. In M. Halonen, P. Ihalainen, \& T. Saarinen (Eds.), Language Policies in Finland and Sweden. Interdisciplinary and multi-sited comparisons (pp. 90-115). Multilingual Matters. https://doi.org/10.21832/9781783092710-006

All material supplied via JYX is protected by copyright and other intellectual property rights, and duplication or sale of all or part of any of the repository collections is not permitted, except that material may be duplicated by you for your research use or educational purposes in electronic or print form. You must obtain permission for any other use. Electronic or print copies may not be offered, whether for sale or otherwise to anyone who is not an authorised user. 
Mika Lähteenmäki and Sari Pöyhönen

\section{Language rights of the Russian-speaking minority in Finland: Multi-sited historical arguments and language ideologies}

The present chapter discusses the current status of Russian in Finland and also addresses the question of the language rights of the Russian-speaking minority, which has become a globally significant topic due to the rapid growth of the Russian-speaking diaspora after the collapse of the Soviet Union. The motivation for this discussion is two-fold: First, the current status of Russian, which has become the third most spoken language in Finland as a result of intensive migration during the past two decades, can be seen as analogous to the status of Finnish in Sweden, which had become a significant minority language due to a massive flow of migrants from Finland to Sweden in the 1960s and 1970s (see Wickström, Lainio and Snellman in this volume). Second, the official view of Russian as belonging to the category of 'other groups' in the Finnish Constitution (2000; see Ihalainen \& Saarinen in this volume) is compared with the status of Swedish as a 'national language' with the aim of showing that historical arguments can be used in strikingly different ways as justifications for language policy within one country.

The most powerful argument for the status of Swedish in Finnish legislation has traditionally been the historical-cultural argument that emphasises the common history of Sweden and Finland and the role of the Swedish-speaking cultural elite in the creation of Finnish national culture (see Kotilainen in this volume). In the case of Russian, in contrast, the situation seems to be quite the opposite. It will be argued here that the Finnish interpretation of the common history of Russia and Finland, which

plays a central role in the Grand Narrative of Finnishness, downplays the significance of Russia and Russian cultural influence by representing Russia as a potential threat. This narrative, deeply rooted in the collective memory of Finns (see Lähteenmäki \& VanhalaAniszewski, 2012: 125), also underlies current suspicious attitudes towards Russia and Russians (see, e.g. Tanttu, 2008) and may hinder the promotion of its current status in Finnish language legislation.

After a brief overview of the common history of Finland, Sweden and Russia, we will move to the discussion of recent outside reactions on the language situation in Finland. 
The data consist of the monitoring cycles of the European Charter for Regional or Minority Language (Council of Europe 1992), Framework Convention on the Protection of National Minorities (Council of Europe 1995), and the statements and initiatives to promote the role of Russian as a minority language outside the Russian Federation by the Russian Government and the Russkiy Mir Foundation (Russian World). We will focus on how Russian-speaking language communities are described in these documents, how language rights are represented, and what the main arguments for the promotion of the rights of the speakers of minority languages are. Our assumption is that while the responses of the Council of Europe and the Russian counterparts to the language policy of Finland and the status of Russian in particular share a common goal, namely the promotion of the language rights of the Russian-speaking minority, the political and ideological agendas as well as the underlying conception of the relationship between language, individual and society are significantly different. Finally, the findings will be discussed against the backdrop of Finnish language legislation and current language policy discourse in Finland.

The present discussion is based on the assumption that formal language policy discourse, including language legislation, represents the most institutional and normative form of language ideological discourse. While all acts of ideological construction, including language policy, manifest themselves in a particular context, they can also be seen as part of more general socio-political and historical processes taking place in a particular society (Blommaert, 1999: 2). Thus, language policy discourses are essentially multi-sited in the sense that particular discourses are both rooted in the history of a particular society (vertical dimension) and connected to other relevant contemporary discourses (horizontal dimension) produced by different actors and stakeholders (see Halonen, Ihalainen \& Saarinen in this volume). An important methodological implication for the analysis of language policy discourses that follows from the multi-sitedness is that apart from the immediate context the analysis has to take into account also wider political, historical and cultural contexts in order to reveal the ways in which particular language political views and language policy have been and are being articulated. In order to illustrate the horizontal dimension of multi-sitedness, we have chosen two different sets of data that shed light on the language situation in Finland from their respective perspectives. 


\section{Russian in Finland: Historical background}

Apart from the Finnish-Swedish state bilingualism of the country, the large and fast growing number of speakers of Russian compared to other language groups is a characteristic feature of the linguistic landscape in Finland. While in 1990 the number of Russian-speaking people living in Finland was 3,884, at the end of 2010 there were over 55,000 persons living permanently in Finland who declared Russian as their first language (Statistics Finland, 2012). The rapid rise in the number of Russian-speakers is explained by the substantial immigration of people with an Ingrian-Finnish background to Finland in the 1990s after President Mauno Koivisto had stated, in 1990, that people descending from the Finnish-speaking Lutheran people who settled the Orthodox Ingrian-speaking territory during the Swedish rule would be treated as repatriates in case they wished to migrate to Finland from the former Soviet Union. Even though the percentage of Russian-speaking persons (1 per cent) is currently still very low compared to the percentage of the speakers of Finnish (90 per cent) and Swedish ( 5 per cent), in the majority of the municipalities of Finland the number of speakers of Russian is higher than the that of speakers of Swedish (Statistics of Finland, 2009). In addition, there are municipalities in Eastern Finland in which the number of Russian-speaking persons comprises 3.5 per cent of the population (Statistics of Finland, 2009). This is explained by the fact that the Swedish-speaking population is concentrated on the West and South coast of Finland, and in the Helsinki metropolitan area.

The Russian-speaking population in Finland is intimately linked with the long common history of Finland, Russia and Sweden characterised by conflicts and shifts of borders. At the time when most of the territory of present-day Finland was part of the Kingdom of Sweden (from the thirteenth century to 1809), there were different forms of crossborder contacts and conflicts between Finns, Karelians, Ingrians and Russians living on both sides of the border between Sweden and Russia. Before the collapse of the Soviet Union in 1991 Russian-speakers migrated to Finland in three waves. The first wave took place in the early eighteenth century comprising serfs and farmers who moved to the province of Karelia which had been lost by Sweden to Russia. The second wave consisted of civil servants, merchants and military who migrated to the autonomous 
Grand Duchy of Finland from other parts of the Russian Empire in the period of autonomy in the nineteenth century. In addition to this, the Karelian Isthmus was a popular summer resort for approximately 100,000 Russians who resided in Saint Petersburg. The third wave of migration comprised people who fled Soviet Russia after the October Revolution in 1917 and immigrated to Finland which had gained its independence in 1917.

The Russian-speaking people and their ancestors who moved to Finland before the collapse of the Soviet Union have until very recently been called the 'Old Russians', most of whom have been totally assimilated and changed their language to Finnish or Swedish (see e.g. Niemi, 2007). The term 'New Russians' has been used to refer to the Russian-speaking population that settled in Finland during the perestroika and after the collapse of the Soviet Union. 'New Russians' is a somewhat imprecise name for an ethnically, culturally, religiously and linguistically heterogeneous group that comprises Orthodox and Lutheran Ingrians most of whom had become linguistically and culturally Russian during the Soviet period, ethnic Russians most of whom have moved to Finland as a result of Finnish-Russian marriages or work-related migration and, finally, members of other ethnic groups of the former Soviet Union whose main language was Russian. Thus, the Russian-speaking population of Finland represents a heterogeneous group within which the ethnic, cultural and linguistic identities are multiple and increasingly situated in time and space (Lähteenmäki \& Vanhala-Aniszewski, 2010; Rynkänen \& Pöyhönen, 2010). By this we mean that in the era of late modernity which is characterised by growing mobility of people and social, economic and cultural globalisation, the identity of an individual can rarely be anchored to the conventional categories of geography, history or language which have played a crucial role in the creation of nation-states in Europe (see Smyth, forthcoming). Moreover, as the collapse of the Soviet Union in 1991 shows, even those anchor points that are often taken as given and can be a significant part of the identity of an individual (e.g. country of origin) may cease to exist, which necessarily forces the individual to reconsider and redefine her identity in the changed context.

As to the status of Russian in present-day Finland, we argue that the project of construing the Finnish nation since the nineteenth century and its interpretation of the common history of Finland, Russia and Sweden are still relevant and affect the ways in 
which the roles of Russian and Swedish are articulated in Finnish language legislation and language policy discourse in general. The Finnish-Swedish state bilingualism has its roots in the common history of Finland and Sweden. Indeed, it is a historical fact that the Swedish-speaking population of the Grand Duchy of Finland played a central role in the development of the Finnish language, culture, nation state and Finnish national identity. For instance, a significant number of Fennomans, whose aim was to promote the development of the Finnish language and culture in the nineteenth century, spoke Swedish as their mother tongue (see Kotilainen in this volume for details). The prominent role of the Swedish-speaking cultural elite in the formation of Finnish culture and national identity is seen as an important historical justification and argument for the current status of Swedish in Finland. However, the way in which the 'common history' discourse is used in the discussion about the status of Russian in Finland is radically different from that of Swedish (for a detailed discussion, see Lähteenmäki \& Vanhala-Aniszewski, 2012). The idea of Russia and 'Russianness' as primordial enemies and potential threats to Finland and 'Finnishness' have long historical roots and play a prominent role in the Grand Narrative of Finnishness (see Tarkiainen, 1986; Vilkuna, 2006). The fear of Russia, Russian and the Orthodox religion is also present in the Finnish folklore and local history (see Leppänen \& Pahta, 2012), in addition to which it has been further strengthened by the events in the more recent history of the countries. These include the first (1899-1905) and second (1909-17) eras of oppression during which the aim of the Russian chauvinist politics was to subdue the growing nationalist movement in Finland and fully integrate the Grand Duchy of Finland into the Russian Empire (Jussila, 2004; Zetterberg, 2005). Also the Winter War (1939-1940) and the Continuation War (1941-44) between Finland and the Soviet Union have been interpreted as demonstrations of aggressiveness of Russia. In 1948 the countries concluded the Treaty of Friendship, Cooperation and Mutual Assistance as a consequence of which the Cold War period Finnish foreign politics were characterised by so-called Finlandisation, that is, deliberate attempts not to question the foreign policy interests of the Soviet Union.

Thus, the contemporary discourse on language policy and the status of Russian in particular is deeply rooted in the historical narrative which presents Russia as an enemy and potential threat to Finnishness. From the pervasiveness of this narrative, 
which plays a significant role in the Grand Narrative of Finnishness, it follows that the promotion of the language rights of the Russian-speaking minority is even today a politically sensitive topic with a great historical burden. The same mechanism is also at work in discourses about the status of Swedish, although it seems to mostly work in the opposite direction. The power of the narrative of the 'common history' of Finland and Sweden is also reflected in the Finnish parliamentary discourse which tends to maintain the current status of Swedish and avoids any reconsideration of the Finnish language policy as a whole (Ihalainen \& Saarinen in this volume). Next, we will analyse how and to what extent, if at all, the articulation of the Grand Narrative of Finnishness and the ideological views concerning the common history of Finland and Russia, which underlie contemporary language policy discourse in Finland, are reflected in the reactions of the Council of Europe to the current status of Russian in Finland.

\section{Language rights and the Russian-speakers: A European view on the Finnish policies}

There are two treaties of the Council of Europe that deal with language rights, namely the European Charter for Regional or Minority Languages (1992, henceforth ECRML or Charter) and the Framework Convention for the Protection of National Minorities (1995, henceforth, FCPNM or Convention), which also have been signed and ratified by

Finland. The data for the analysis of the reactions and recommendations concerning the status of Russian in Finland by the Council of Europe consist mainly of the monitoring cycles of the Charter. A special focus will be on the ways in which the Russian language and speakers of Russian have been represented and conceptualised in both the Finnish Government reports and the expert and advisory committee documents by the Council of Europe.

The main aim of the ECRML is to strengthen the position of regional and minority languages as part of European heritage, and develop their status among European hegemonic languages. The regional or minority languages are defined as languages which are '1) traditionally used within a given territory of a State by nationals of the State who form a group numerically smaller than the rest of the State's population; and 2) different from the official language(s) of the State' (Council of Europe, 1992: 2-3). 
The Charter does not define 'a traditionally used language' in terms of time, and it is largely up to the member states (parties) to determine how and to which languages this concept is applied (Council of Europe, n.d.), which has led to quite different applications in the case of Finnish in Sweden and that of Russian in Finland, for instance. The Charter aspires to promote the right to use a regional or minority language in both private and public life. The ECRML also aims at protecting small, diminishing languages, which are used by the citizens in the countries that have signed and ratified the Charter. It is noteworthy that neither 'dialects of the official language(s) of the State' nor 'the languages of migrants' are included in the ECRML as categories of languages needing protection (Council of Europe, 1992: 2).

A central concept used in the characterisations of the statuses of different languages in the Charter is territory which refers to 'the geographical area in which the said language is the mode of expression of a number of people justifying the adoption of the various protective and promotional measures provided for in this Charter' (Council of Europe, 1992: 2). The Charter makes a distinction between territorial and non-territorial languages, the latter being defined as

languages used by nationals of the State which differ from the language or languages used by the rest of the State's population but which, although traditionally used within the territory of the State, cannot be identified with a particular area thereof (Council of Europe, 1992: 2-3).

The Charter consists of five Parts. In Parts I and II, the Charter defines general provisions (e.g. definitions), objectives and principles on which the parties should base their policies, legislation and practice regarding regional or minority languages. Part III, the most extensive part of the Charter, consists of a list of measures for the promotion of the use of regional and minority languages in public life, including education, judicial authorities, administrative authorities and public services, media, cultural activities and facilities, and economic and social life. Part IV is devoted to the applications of the Charter, while Part V contains the final provisions.

Finland has submitted reports on the realisation of the measures recommended in the Charter every three years. The first report appeared in 1999, and the reports have been evaluated by the Council of Europe four times. Finland submitted the fourth and most 
recent periodic report on the application of the ECRML in Finland in September 2010 which was followed by the report of the Committee of Experts and the recommendations of the Committee of Ministers published in March 2012. In the first report of the Finnish Government (1999a: 1) Finland declared that it will apply 65 of the provisions under Part III to the Swedish language as the less widely used official language and 59 to the Sámi language as a regional language (the minimum number of paragraphs or sub-paragraphs to be chosen is 35 in Part III). In addition, Finland declared that it will undertake to apply (mutatis mutandis) the principles of Part II to the Roma language as well as to other non-territorial languages spoken in Finland. In the first report the languages included in this category were Russian and Tatar (Government of Finland, 1999a: 6).

It should be pointed out that the information about the exact composition of the Committee of Experts is not publicly available, but there are certain regulations concerning its constellation. According to the Explanatory Report on the ECRML (Council of Europe, n.d., Part IV, Articles 15-17, paragraph 131)

The number of members of the committee of experts will be the same as the number of parties to the charter. They must be persons of recognised competence in the field of regional or minority languages. At the same time, by placing emphasis on the intrinsically personal trait of the 'highest integrity', the charter makes clear that the experts appointed to the committee, in carrying out their task, should be free to act independently and not be subject to instructions from the governments concerned.

It is also considered important that a substantial part of the members of the Committee are either legal experts or experts in sociolinguistics. For some time the proportional size of these two expert categories has been slightly less than 50 per cent each of the total number of members. The Committee also includes other experts who have been appointed on the basis of their competence in the field of regional or minority languages, including teachers, former diplomats, former Members of the European Parliament and so forth. The Chair has been a legal expert, as have the Vice Chairs. Regarding the personal background of the members, there is no general preference to choose the experts from the speaker groups of the concerned regional or minority languages, even if this in practice is occasionally the case: it is the individual's personal 
integrity that is decisive. The internal procedures of naming the candidates for appointment may also differ between nation states. (Jarmo Lainio, oral communication 7 March 2013.)

As mentioned above, the second important document relating to language rights within the Council of Europe is the Framework Convention for the Protection of National Minorities. The Convention defines the basic principles relating to the protection of national minorities in their own territory, and also lists the obligations of the countries that have signed and ratified the treaty. The chief aim of the obligations is to strengthen the protection against discrimination and to maintain and develop minority cultures. As to the implementation of the recommendations of the Convention, the Government of Finland has submitted three reports since 1999, the latest Government report dating from February 2010. The Advisory Committee published its response to the latest report together with the comments of the Government of Finland in April 2011. The final resolution and the recommendations of the Committee of Ministers appeared in February and March 2012. According to the Explanatory report on the Framework Convention for the Protection of National Minorities (Council of Europe, n.d., Section IV, Articles 24-26, paragraph 96), the Committee of Ministers will determine 'the composition and the procedures of the advisory committee, the members of which shall have recognised expertise in the field of the protection of national minorities'.

Article 5 of the Convention (Council of Europe, 1995: 3) states that the parties are expected to

promote the conditions necessary for persons belonging to national minorities to maintain and develop their culture, and to preserve the essential elements of their identity, namely their religion, language, traditions and cultural heritage.

The text of the Convention does not provide any explicit definition of the notion of national minorities and, consequently, it remains unclear what this central concept refers to. An attempt to characterise national minorities in terms of territory, tradition and number can be found in Article 10 (Council of Europe, 1995: 4-5) which states that

in areas inhabited by persons belonging to national minorities traditionally or in substantial numbers, if those persons so request and where such a request 
corresponds to real need, the Parties shall endeavour to ensure, as far as possible, the conditions which would make it possible to use minority language in relations between those persons and the administrative authorities.

That the notion of national minorities had been left undefined at the moment of the ratification of the Convention was also pointed out in the first report submitted by the Government of Finland (1999b: 3). From this it followed that the passages of the treaty which describe the national minorities in Finland were based on earlier documents containing an overview of the history of the Sámi, the Roma, the Jews, the Tatars, Old Russians and Swedish-speaking Finns in Finland that had been submitted to UN treaty bodies, referred in the Convention.

The ambivalence of the notion of national minorities is also reflected in the discussion of the language rights of the speakers of Russian in the sense that it is not always clear who are included in the Russian-speaking minority. The first periodical report on the implementation of the ECMRL submitted by the Government [of Finland] in 1999 makes a distinction between the 'Old Russians' and 'New Russians', whereas the relevance of the distinction for the discussion of language rights in the contemporary context is seriously questioned in the report of the Committee of Experts that appeared two years later:

At this moment there are some 20,000 Russian-speaking persons living in Finland, of which some 5,000 are so-called Old Russians (Government of Finland, 1999a: 6).

Russian is a traditional language in Finland. The Russian-speakers form a rather heterogeneous group of about 5,000 so-called Old Russians, of whom only a part has maintained the Russian language, and 15,000-25,000 New Russians, depending on the time of their arrival in Finland. The Committee has however decided to consider this language without the distinction of whether its users are 'new' or 'old'. (Council of Europe, 2001: 8.)

The Government report does not comment on the language itself, but refers to 'Russianspeaking persons' who are divided into two separate groups. The Expert group report, in contrast, disclaims the distinction between the 'old' and 'new' Russians and states 
that the language is the same irrespective of the fact that the speakers of Russian form a heterogeneous group. It is difficult to say whether Finland has made the distinction in order to categorise the 'New Russians' as belonging to the group of migrants, in which case they would not be included in the treaty. During the process of drafting the report the Government of Finland had consulted the Russian Cultural-Democratic Union (Russkii kul'turno-demokraticheskii soiuz) associated with the 'Old Russians', whereas representatives from other organisations of Russian-speakers were not contacted. This can be explained by the fact that FARO, The Finnish Association of Russian-Speaking Organisations, was established the same year as Finland had submitted its first report. A question remains, though: Why was it important for Finland to make the distinction between the two groups of Russian-speaking people in the report? On the one hand, a possible explanation is that Finland followed the practice adopted in the Framework convention where the 'Old Russians' were defined as a national minority [in Finland]. On the other, this categorisation would allow the government to treat 'New Russians' as a recent migrant group in which case the Russian-speaking minority would not be entitled to the rights listed in the ECMRL, since the language rights of migrants are not covered by the Charter.

The second and third periodical reports on the Charter by the Finnish Government (Government of Finland, 2002: 11, 2006: 9) provide a wider perspective into the uses of the terms 'Russian' and 'Russian-speakers'. The second report mentions that 'while Swedish-speakers are the largest language minority in Finland, the Russian-speaking persons constitute the largest non-territorial language group'. The distinction between the 'Old Russians' and 'New Russians' is no longer used, but the Government reports refer to the 'historical Russian-speaking minority/population' as opposed to 'immigrants/new immigrants' thus effectively recapitulating the earlier distinction. What is more, 'many Ingrian returnees', who had been granted the status of repatriates on the basis of their Finnish origins, are included in the Russian-speaking population, although the report emphasises at the same time that 'many of them nevertheless wish to maintain their Finnish identity' (Government of Finland, 2006: 9). The Government reports characterise the promotion of the language rights of the Russian-speaking minority as 'challenging' as a result of the heterogeneity of the group. Both periodical reports also acknowledge 'the enterprising spirit of Russians in Finland, which has 
contributed to the strengthening of their identity and culture' (Government of Finland, 2006: 9; emphasis added). The use of the expression 'Russians' in this context would seem to imply that Russian-speaking people are understood as an ethnic group, whereas elsewhere in the reports the expressions used are 'Russian-speaking population/population group/minority/persons' and there are several references to the heterogeneous nature of the group.

The second evaluation report (Council of Europe, 2004: 6) of the Charter comes back to the issue of the relevance of the distinction between the 'Old' and 'New' Russians for the description of the situation of the Russian language in Finland. The evaluation report starts with an estimation of the number of Russian-speaking people in Finland and then continues by stating that 'this figure includes the so-called "old Russians", "new Russians" who are migrants, as well as the Ingrian returnees'. Thus, the distinction between the 'Old' and 'New' Russians has been replaced with the tripartite distinction between a historical national minority, recent immigrants and repatriates. The third evaluation report (Council of Europe, 2007: 5) disclaims both distinctions and merely acknowledges that 'the Russian-speaking population is not a unified group and due to the different backgrounds their condition in the Finnish society varies'.

The third periodic report on the Framework Convention (Government of Finland, 2010b: 18) states that 'the different Russian-speaking groups' are treated equally with regard to the provision of services and support. The report also adds that "no distinction is drawn between "the Old Russians" and the other Russians or Russian-speaking people belonging to the population of Finland'. The Advisory Committee had encouraged the Finnish authorities to re-examine the justifications for the distinction between the two groups in its previous periodical Opinion (Council of Europe, 2006), and in its third Opinion (Council of Europe, 2010) the Advisory Committee was 'pleased to note' that the distinction between the 'Old Russians' and 'New Russians' was no longer upheld in the documents submitted by the Government of Finland. Elsewhere in its report the Advisory Committee continues to use the expression 'the Russianspeaking minority'.

The fourth and most recent report of the Committee of the Experts (Council of Europe, 2012: 18) of the ECMRL pays attention to the fact that there are increasingly negative 
attitudes towards Russian-speaking people in Finland, and refers particularly to the recently immigrated part of the group. The report describes the worries of the speakers' that Russian is portrayed in a negative light in the Finnish media, and 'young people do not always dare to use their mother tongue in public'. Similar negative attitudes towards the Swedish language have also been reported, with an emphasis on the political debate regarding the mandatory position of Swedish in Finnish schools as well as the protection of the language rights of the Swedish-speakers during the latest regional administrative reform, concerning among other things health care. The report of the Committee of the Experts characterises the status of Swedish as a second official language as 'fragile' (see Ihalainen \& Saarinen in this volume on the position of Swedish in the legislation).

The latest report of the Committee of the Experts (Council of Europe, 2012: 11) puts more pressure on Finland and requires the Government to take more efficient measures for the protection of Russian as a regional or minority language in addition to which it pays attention to permanent problems in establishing a dialogue between the representatives of the Russian-speakers and the Finnish Government. The report also refers to the earlier recommendations by the Council of Europe with regard to the availability of Russian language education for the speakers of the language and concludes that Finland has not succeeded in meeting the needs of the Russian-speaking minority and no significant improvement has taken place (see also Council of Europe, 2010: 30). The Experts' report states that 'the most serious difficulty lies in the fact that it [Russian] is not treated as a regional or a minority language'. What is more, apart from preventing an increase in negative attitudes towards Swedish-speaking and Romani people, the Committee of Experts (Council of Europe, 2012: 18) 'encourages' the Finnish authorities to 'take measures to promote tolerance and raise awareness among the majority population about the Russian language as an integral part of the Finnish culture'. This recommendation, which ascribes to [the] Russian [language] the same role in the development of Finnish culture that has traditionally been attributed to Swedish, assumes that historical arguments and justifications are an essential tool for 'promoting tolerance'. While the idea that knowledge of history helps to understand and cope with present-day phenomena is most welcome, the formulation seems to ignore the cultural fact that the traditional interpretation of the role of the common history of 
Finland and Russia in the construction of the Grand Narrative of 'Finnishness' is radically different from that suggested by the Committee of Experts. The passages above represent the strongest and most explicit criticism of the current status of Russian in Finland in the documents produced by the Council of Europe. Next, we will turn to Russian legislative documents and language policy discourse dealing with the language rights of Russian-speaking people residing in the Russian Federation and across the globe, which contain a particular ideological view concerning the interrelationship of language, culture and nation. While these documents address the question of language rights of the Russian-speaking diaspora on a general level, they have, by definition, a direct bearing on the language rights of the Russian-speaking population in Finland.

\section{Language policy and the language rights of Russian-speaking people in Russian language policy discourse}

Russian is considered one of the 'world languages' which ranks eighth in the list of the most widely spoken languages of the world and is spoken in 33 different countries (see e.g. Ethnologue). According to different estimates, there are currently approximately 140-160 million first-language speakers of Russian, whereas the total number of Russian speakers, including those for whom Russian is a second language, is approximately 220-280 million. However, it has been estimated that the number of Russian speakers will fall significantly in the near future. According to Aref'ev (2006), the number of Russian first-language speakers in the Russian Federation will fall from 140 million (2004) to 110 million by 2025. The decrease in the total number of speakers of Russian around the world is expected to be even more dramatic. It has been estimated that it will drop from 278 million (2004) to 152 million by 2025 (Aref'ev, 2006).

There are at least two main reasons for the rapid decrease in the number of Russianspeaking people. First, the population of the Russian Federation is expected to decrease in the near future due to the low birth rate and low life expectancy among its citizens. Second, the dramatic fall in the total number of Russian-speakers around the world is explained by the fact that a significant number of current Russian-speakers are first generation migrants living outside the Russian Federation (the former republics of the 
USSR, USA, Canada, Israel, Germany, Finland and so forth) and, consequently, their children and grandchildren are less likely to speak Russian to the same extent as their parents and grandparents. This demographic development together with the decreasing number of speakers of Russian has been met with concern by Russian officials, including President Vladimir Putin, because this development presents a potential threat to Russia's status among superpowers and the status of the Russian language among world languages. This is naturally reflected in Russian language policy discourse and the official language policy of the Russian Federation which express the concern about the future of Russian among other large languages.

A concrete manifestation of the concern about the future of Russian is the introduction of the new Language Act 'On State Language of the Russian Federation' (henceforth ZGIaRF) adopted in May 20, 2005 (for discussion, see Pyykkö 2010). Together with the Constitution of the Russian Federation, the law defines the status of the Russian language as the state language, in addition to which Russian is seen as an essential tool for promoting mutual understanding and strengthening bonds between different nations in the unified state. The law on state language represents a particular ideological view concerning the interrelationship of the concepts of language, culture and nation. For instance, it states that

the protection and the support of the Russian language as the state language of the Russian Federation promote the increase and mutual enrichment of the spiritual culture of the peoples of the Russian Federation ${ }^{1}$. (ZGIaRF, §1, 5.)

In contrast to the Humboldtian idea of a linguistic Weltanschauung which assumes an intimate connection between the spiritual and cultural capacity of a nation and its language, the above formulation contains a somewhat different view on the connection between language, culture and nation. The Russian language is seen as an important source and expression of both the Russian national culture and the national cultures of those peoples that reside in the territory of Russia. Thus, the Russian language is given a special role among the languages spoken in Russia in the sense that the protection and support of Russian are seen as an important means for mutual enrichment of the

\footnotetext{
${ }^{1}$ The documents that comprise the data of this section have been published in both Russian and English. To save space, the authorized English versions of the documents have been used.
} 
spiritual culture of all nations within the territory of the Russian Federation. The common language is seen as an important ingredient in the identity and unity of the Federation, whereas in Swedish language policy discourse the same idea of 'one language for all' is presented as a necessary prerequisite for access to Swedish society (see Ihalainen \& Saarinen in this volume). Apart from its role as the expression of Russian spiritual culture, Russian is represented as an international semiotic master key capable of contributing to the development of all national cultures. The characterisation of the Russian Federation as 'a unified multinational state' (ZGIaRF, §1, 4) is clearly motivated by and dependent on the hegemonic status attributed to Russian as both the state language and the unifying language of intercultural communication in the Russian Federation.

It can be argued that the idea of unified multinationality echoes the imperialistic understanding of the role of the former Russian Empire as a unified multinational space which is the spiritual home of a multiplicity of linguistically, confessionally and ethnically diversified groups (see Gerasimov et al., 2009). This idea remained basically intact after the October Revolution despite the anti-imperialist proclamations of the Bolshevik regime. While Bolsheviks originally had condemned all forms of imperialistic colonisation characteristic of the Tsarist Russian Empire and emphasised the importance of the national self-determination of its peoples, the nationality question became acute in the very first years of the Soviet Union. In order to secure access to necessary natural resources located in the non-Russian republics of the Soviet state, the Bolshevik regime, with the help of former imperial economists, developed a programme of Soviet colonisation, effectively recapitulating the idea of the former Russian Empire in Marxist-Leninist terms (Hirsch, 2005: 6-7). The continuity between the Tsarist Russia and the Soviet Union has also been emphasised by Suny (2001: 26) according to whom neither pre-revolutionary Russia nor the Soviet Union was ever [an] ethnically Russian [empire], because the ruling institutions (the nobility and the Communist nomenklatura) were always multinational, although they were predominantly Russian by nationality and 'ruled imperially over Russian and non-Russian subjects alike'. What is known as today's Russia has been linguistically and culturally diverse from the very beginning, and the 'Russian idea' was never based on national unity. 
As pointed out by Hobsbawm (1990: 57), the belief in the unifying power of a shared language has produced a 'sort of platonic idea of language, existing behind and above all its variant and imperfect versions' which is then protected through language policy and legislation. In language policy this quest for the uniformity and normativity of a particular language is manifested in various practices of standardisation and codification. According to Wright (2007: 205), the idea of a shared unified language raises a genuine question for language policy makers: what is the language that needs protection, an ideal system outside of its speakers or the diversified and heterogeneous reality of actual linguistic practice? Moreover, the idea of 'perfect' language is sometimes present in linguistic research as well in the sense that migrant variants of Russian spoken in different countries are not studied on their own terms as different variants of Russian, but evaluated against some hypothetical standard provided by the normative 'real' Russian language residing in a Platonic realm (for a critical discussion, see Rynkänen \& Pöyhönen, 2010).

While the law 'On State Language of the Russian Federation' mainly defines the status of the Russian language within the Russian Federation, recent Russian discussions of language policy and language rights have focused on the rights and possibilities of the Russian-speaking people living outside the Russian Federation to preserve their linguistic and cultural heritage. These considerations apply, by definition, to the language rights of the Russian-speaking population in Finland. There has been a growing concern about the language rights of those Russian-speaking people who live in the former republics of the Soviet Union, which in current Russian discourse are referred to as 'the Near Abroad', and became diasporised linguistic minorities without leaving their home countries. The expression 'the Near Abroad' (ближнее зарубежье) is an ideologically loaded metaphor that echoes the age-old imperialistic idea of Russia characterised by multinational unity. In addition to this 'stranded' or 'beached' diaspora, there also exist 'genuinely' diasporic communities, that is, growing Russian-speaking communities, some with a long history, in different parts of the world, including Finland. As a consequence of this sudden large-scale diasporisation of Russian-speaking people, who may or may not have Russian citizenship, the Russian Federation has become extremely concerned about the protection of their language rights in their new home countries. Another manifestation of the same political rhetoric is the recent 
controversial law that prohibits the adoption of Russian children to the United States due to the alleged cases of child abuse among children adopted from Russia. It seems that these concerns are motivated, at least in part, by the demographic crisis that is expected to face Russia in the near future. This crisis together with the large-scale diasporisation of Russian-speaking people will lead to a decrease in the number of speakers of Russian. In this light it seems that the chief aim of the recent provocative outbursts mentioned above is to convince Russians that Russia is the best place to live for a Russian, and warn those who may think about emigrating from Russia that the conditions are much worse abroad.

Apart from defending the language rights of the Russian-speaking diasporas in different countries, the language legislation of the Russian Federation, together with other governmental documents, also touches upon the place of the Russian language among 'world languages'. While the existing law on state language is primarily aimed at the promotion of the use of Russian as the state language within the Russian Federation, there are also passages dealing with promoting the use and study of Russian outside Russia to strengthen its role as a language of international communication (see ZGIaRF, $\S 4,4)$. More explicit views regarding the role of Russian as one of the 'world languages' and defending the language rights of Russian-speaking people living outside the Russian Federation can be found in the document "The Foreign Policy Concept of the Russian Federation' (henceforth FPCRF).

'The Foreign Policy Concept of the Russian Federation', which was approved by the President Putin in June, 2008, is a document that defines the system of views regarding the foreign policy of the Russian Federation. One of the general goals mentioned in this document is the comprehensive protection of the rights and interests of Russian citizens and compatriots abroad' (FPCRF, §1). A recent manifestation of this protective action is the document 'On the status of human rights in several countries of the world' published by the Ministry of Foreign Affairs of the Russian Federation' (MIDRF, 2011). Among other things, this highly controversial and programmatic document discusses at considerable length the situation of human rights in Finland and lists the discrimination of refugees and immigrants as well as 'the lack of a distinct national policy in relation to the Russian-speaking population' (MIDRF, 2011: 43). From the point of view of the present discussion, it is noteworthy that the protection of the rights of the Russian- 
speaking diaspora includes 'the expansion and strengthening of the space of the Russian language and culture' (FPCRF, §5) in their countries of residence. Apart from protecting the rights of the Russian-speaking diaspora to preserve their linguistic and cultural identity, the document also aims to enhance the status of Russian among the world languages by contributing to 'learning and spread of the Russian language as an integral part of the world culture and an instrument of inter-ethnic communication' (FPCRF, §5).

A significant function of the foreign policy activities of the Russian Federation is the preservation of the ethnic and cultural identity of the Russian diaspora and its links with its historic motherland' (FPCRF, §5). This formulation seems to assume the Herderian idea of an inseparable link between language, culture, ethnicity and territory, thereby ignoring the heterogeneous nature of the Russian-speaking diaspora. For instance, the Russian Federation was never the homeland of Russian-speaking people living in the newly independent countries that were former republics of the Soviet Union, who simply decided to stay in their home countries after the declaration of independence and consequently became linguistic minorities (Pavlenko, 2008: 30). Although the first generation of the Russian-speaking linguistic minorities was born in the Soviet Union, their children were born in independent countries with no connection to the Russian Federation. This discourse also seems to take monolingualism as a norm, thus ignoring the fact that the people being referred to are factually multilingual. The underlying assumption that regardless of the country of birth or residence, an individual who has Russian-speaking ancestors and speaks Russian automatically connects herself to the 'historic motherland' and its spiritual culture is highly idealised and dated in the contemporary world characterised by mobility and growing postnationalism (Heller, 2011). In fact, the very applicability of the concept of diaspora can be questioned, because it implies that the members of diaspora live 'in a society distant from the homeland [...] and to which they one day expect to return' (Laitin, 1998: 29).

Apart from the legislation and official documents, the language rights of the Russianspeaking diaspora are being actively discussed by various organisations supported by the government of the Russian Federation. In recent years one of the most active and prominent organisations has been the Russkiy Mir Foundation which was established by President Putin and is a joint venture of the Ministry of Foreign Affairs and the Ministry of Education and Science. The foundation sees its main goal in promoting 'the 
Russian language, as Russia's national heritage and a significant aspect of Russian and world culture, and supporting Russian language teaching programs abroad' (RM). It also aims to enhance the international visibility and 'the appreciation of Russian language, heritage and culture' (RM). While the chief goal of the organisation, which has been articulated explicitly in various documents, is to enhance the international recognition of the cultural values associated with the Russian language and the history of Russia, its activities have a clear political and economic agenda the aim of which is to gain recognition for the role of Russia as one of the superpowers.

In his address delivered at the Federal Assembly of the Russkiy Mir Foundation in 2007, President Putin stated that

The Russian language not only preserves an entire layer of truly global achievements but is also the living space for the many millions of people in the Russian-speaking world, a community that goes far beyond Russia itself. As the common heritage of many peoples, the Russian language will never become the language of hatred or enmity, xenophobia or isolationism. (RMF.)

Here, the Russian language is conceptualised by using two different metaphors. Firstly, it is seen as a layered container or reservoir of cultural, scientific, technological and so forth achievements of its speakers. While it assumes that a language is a true expression of the spirit of its speakers as well as their history and culture, the formulation emphasises that the achievements associated with the Russian language and culture are not only nationally significant but have a 'truly global' significance. Instead of viewing Russian as a national language it is given a universal role. What is more, not only are the achievements preserved in the Russian language characterised as global, but neither is the language itself seen as the sole property of the people residing in historic Russia and the expression of Russian national culture but characterised as the 'heritage of many peoples.' Thus, the above passage presents an interesting mixture of the imperialistic understanding of the history of Russia as a unified space and spiritual home of all of its 'many peoples' combined with an aspiration for making Russian a global language. Secondly, the Russian language is conceptualised as 'the living space' for the speakers of Russian that extends beyond the territory of the Russian Federation. Thus, 'space' is not tied to a particular location or geographical context but is conceived of as a translocal 
space that exists simultaneously in different geographical locations around the globe and has a wider globally significant dimension as well. In the mission statement of the Russkiy Mir Foundation this space is referred to as 'the Russian world' or 'Russian community' which is not limited to the territory and population of the Russian Federation but also includes those 'millions of ethnic Russians, native Russian speakers, their families and descendants' who live in diasporic communities across the globe.

This type of fluctuation between local and global points of view is also apparent elsewhere. It is argued that Russia as a multicultural society has made significant contributions to global culture, but at the same time it is emphasised that the writers, artists, composers and other cultural figures coming from this multicultural society 'continue spreading and uniting Russian language and culture across the globe' (RMF; emphasis added). The characterisations of the Russian language are equally ambivalent. On the one hand, it is seen as something that is 'at the heart of Russian culture and society' (RMF), thus establishing an unbreakable link between a language and culture. On the other, Russian was in other instances characterised as the 'heritage of many peoples', which is supposed to make it an ideal language for the communication between different peoples due to its hegemonic status within 'the Russian world'.

While the passages cited above acknowledge the translocal nature of the current 'Russian world' as a specific linguistic and cultural space, this translocality is not considered as a desirable property but a potential threat to the unity of 'the Russian community'. Accordingly, the aim of the activities of the Russkiy Mir Foundation is to reconnect 'the Russian diaspora' with their homeland, which seems to be taken to refer to Russia irrespective of the country of birth or residence of a particular Russianspeaking individual. It is taken for granted that all Russian-speaking people scattered across the world would automatically feel that Russia is their homeland, although they may not be ethnic Russians and may not ever have had Russian citizenship. As argued above, this special emphasis on the Russian language as the unifying feature of 'the Russian world', which overrides national and ethnic heterogeneity as well as the geographical dispersion of its speakers, represents a case of strategic essentialism, a form of imperialistic discourse, the aim of which is to create 'imagined and projected boundaries of groupness' (Gerasimov et al., 2009: 20). It is based on the idea that there exists an inseparable link between language and homeland, and a common language is 
seen as the most important single attribute that unites a particular grouping of people and determines the identity of an individual.

The idea that all speakers of Russian scattered around the globe would automatically feel affinity with the 'Russian world' raises some fundamental questions associated with language rights (see Wright, 2007). Firstly, is it an individual or a group, and which group, whose language rights are to be protected and promoted? It seems that the Russkiy Mir Foundation is primarily interested in strengthening the status of Russia by promoting the unity of the 'Russian community', whereas the linguistic rights of an individual are subordinated to the main goal of the organisation. This presupposes that the linguistic rights of an individual do not have an absolute value but are considered valuable only insofar as their protection contributes to the promotion of the status of the whole 'Russian community'. Secondly, is it possible for an individual to refuse these rights, if she does not identify herself with the group membership imposed on her by the policy makers? The above passages seem to take it for granted that becoming a member of the 'Russian world' is neither a deliberate decision nor a matter of free choice but something that is beyond the control of an individual. Thus, it is assumed that every Russian-speaking person, irrespective of her place of residence, family history and so forth, would automatically identify herself as a member of the 'Russian community' on the basis of the sole fact that she happens to speak Russian.

Recently, it has been argued that due to growing diversity, mobility and inequality produced by increasing economic, social and cultural globalisation there is an urgent need for a re-conceptualisation of the traditional categories of sociolinguistics (see e.g. Heller, 2008, 2011; Blommaert, 2010; Blommaert \& Rampton, 2011). According to Heller (2008: 504-505), the categories and concepts of traditional sociolinguistics are not adequate for understanding the mechanisms behind the changed forms of multilingualism, because they are based on the ideology of modernist nationalism and nation-state reflecting its views on the relation between language, nation, community, identity and so forth. While the need for a re-theorisation of the conceptual and analytical tools of sociolinguistics is widely accepted among its practitioners, the present discussion shows that the discourse of nation-state which emphasises the unifying function of a common language still holds the hegemonic position in Russian 
language policy discourse. It can be argued that the same holds true for the language policy in Finland and Sweden as well, as shown by other articles in this volume.

\section{Chto delat' - What is to be done?}

It has been argued that the current status of Russian in Finland and its relation to Swedish cannot be properly understood without considering the complexities of the long common history of Finland, Sweden and Russia. This is because contemporary language policy discourse, including language legislation, represents a highly normative form of language ideological discourse which is both situated and part of more general historical, cultural and socio-political processes taking place in Finnish society. We have also discussed outside reactions to the status of Russian in Finland, focusing on the treaties and evaluation reports of the Council of Europe, on the one hand, and the law 'On State Language of the Russian Federation', 'The Foreign Policy Concept of the Russian Federation' and the documents of the Russkiy Mir Foundation, on the other. While these documents represent rather different understandings of language policy and justify the need for the protection of linguistic rights from different perspectives, they share the concern for the status of Russian either within the EU or on a global scale. The treaties and evaluation reports of the Council of Europe recommend that the language rights of the Russian-speaking population should be considered more thoroughly. The Council of Europe even criticises the inability of the Finnish authorities to promote the rights of the Russian-speakers and teaching of Russian, and states that in fact Russian is not treated as a regional or minority language at all. This concern about the status of Russian in Finland has also been expressed, either directly or indirectly, by the representatives of the Government of the Russian Federation and in the initiatives formulated by the Russkiy Mir Foundation that criticise the official language policies in the neighbouring countries and aim to promote the language rights of Russian-speaking communities living outside the Russian Federation.

The idea of universal language rights, not to mention their implementation, is highly problematic, for language use, which always involves making deliberate choices on different levels, can be seen as an indicator of power (Wright, 2007: 204). Thus, changes in language legislation and language rights will necessarily cause changes in the power 
relations between languages and their speakers. This link between language and power is also present in the examples from our data which show that that there are tensions between Finnish language policy discourse and the views of outsiders in defining speakers of Russian and notions of Russian language. Whose language is it that is talked about when references are made to the protection of the Russian language (see also Lainio's chapter in this volume on the definitions of Finnish in Sweden as a historical minority language and a language of recent incomers)? In the Finnish Government's periodic reports Russian has been given several meanings: it is referred to as the language of the Old Russians (who have assimilated to either Finnish or Swedish communities and do not necessarily master Russian any longer), language of the recently arrived heterogeneous group of migrants, and a foreign language to be taught for the majority (i.e. Finnish speakers). The fact that Russian is referred to in multiple ways is an important language political act, because the classifications and categorisations of particular languages found in the periodic reports, as well as in language policy documents in general, do not merely function as neutral descriptions of their roles in society, but necessarily establish certain hierarchical power relations between these languages.

The power relations and hierarchy between the languages defined in the Finnish language legislation are discursively upheld in the periodic reports by the Finnish Government, which effectively repeat the spirit of the Finnish Constitution and the Language Act (see Ihalainen and Saarinen in this volume). Finland clearly tries to avoid situations in which the discussion of the language rights of the Russian-speaking minority could be seen as parallel to the argumentation used in the promotion of the language rights of the speakers of Swedish or Sámi. Apart from the power relations between the languages, the discursive strategies used in the periodic reports to the Council of Europe reflect a more fundamental question associated with language policy within another European organisation, namely the European Union: what is the relationship between the language legislation of a sovereign member state and the language policy of the Union? One could also ask whether and to what extent the improvement of the status of the Russian language in one member country (e.g. Finland) would put pressure on those member countries in which the relative number 
of Russian-speaking population is even higher (e.g. Estonia) to change their language legislation.

The documents produced in the Russian Federation share the view that the protection of the language rights of Russian-speaking people is of outmost importance for the future development of the Russian Federation and for the promotion of the Russian language and cultural heritage on a global level. As pointed out above, the aspiration for the growing appreciation of the Russian language and culture cannot be separated from the geopolitical and financial factors associated with Russia's pretension to be recognised as one of the superpowers, although the latter motivation is not explicitly expressed in any of the documents. As to the arguments for the necessity to protect of the language rights of the Russian-speaking people residing across the globe, it is striking that there are no direct references to the right of an individual to use and maintain the language she chooses, but the chief motivation behind the promotion of Russian is to strengthen the unity of the Federation by uniting various diasporic communities into a single unified 'Russian world'.

Current estimates show that the size of the Russian-speaking population will continue to grow in Finland. Thus, the acute need for providing services in Russian (day-care, pre-school education, teaching of the mother tongue and so forth) will not vanish, and it is very likely that both the Council of Europe and the Russian Federation will put more pressure on Finland to improve the current status of the Russian-speaking minority in the country. It should be pointed out that Finnish language policy discourse is by no means uncontested and there have been some regional attempts to challenge the state bilingualism of Finland. A few municipalities located near the Russian border, where the demand for the knowledge of Russian is high, have appealed to the Ministry of Education for authorisation to provide instruction in Russian as a mandatory language in basic education instead of Swedish. However, these applications have been categorically rejected by the Ministry of Education and Culture that has emphasised that there is no need to amend the existing language legislation. Public discussion on the topic is very polarised (see e.g. Ihalainen et al., 2011), and even though the political debate is sometimes heated, there have not been any serious attempts to change the language legislation of the country into the direction in which the Russian language would receive the same status as, for instance, the Sámi languages or the Finnish sign 
language. The multi-voicedness that manifests itself both in the Finnish language policy discourse and in outside reactions to it derives from the multi-sitedness of language ideological and language political discourses and, more importantly, reflects the power relations between the different actors and stakeholders participating in these discourses. Given the estimations according which the number of speakers of Russian in Finland will increase in the near future, it is also likely that the tension between the positions of the different actors and stakeholders will become more profound and the language policy discourse concerning the status of Russian more polarised than today.

\section{References}

Aref'ev, A. (2006) Budet li russkii v chisle mirovykh iazykov v budushchem? Demoskop Weekly 251/252. http://www.demoscope.ru/weekly/2006/0251/tema05.php

Blommaert, J. (1999) The debate is open. In J. Blommaert (ed) Language Ideological Debates (pp. 1-38). Amsterdam: Mouton de Gruyter.

Blommaert, J. (2010) The Sociolinguistics of Globalization. Cambridge: Cambridge University Press.

Blommaert, J. and Rampton, B. (2011) Language and superdiversity. Diversities 13(2), 1-22. Online at http://unesdoc.unesco.org/images/0021/002147/214772e.pdf

Council of Europe (n.d.) European Charter for Regional or Minority Languages. Explanatory report. Strasbourg. Online at http://conventions.coe.int/Treaty/EN/Reports/Html/148.htm

Council of Europe (n.d.) The Framework Convention for the protection of national minorities. Explanatory report. Strasbourg. Online at http://conventions.coe.int/Treaty/en/Reports/Html/157.htm

Council of Europe (1992) European Charter for Regional or Minority Languages. Strasbourg.

Council of Europe (1995) The Framework Convention for the protection of national minorities. Strasbourg.

Council of Europe (2001) Report of the Committee of Experts on the Charter. Application of the Charter in Finland, 1th Monitoring Cycle. ECRML (2001) 3. Online

at http://www.coe.int/t/dg4/education/minlang/Report/EvaluationReports/Finlan dECRML1_en.pdf

Council of Europe (2004) Report of the Committee of Experts on the Charter. Application of the Charter in Finland, 2th Monitoring Cycle. ECRML (2004) 7. Online http://www.coe.int/t/dg4/education/minlang/Report/EvaluationReports/Finlan dECRML2_en.pdf

Council of Europe (2007) Report of the Committee of Experts on the Charter. Application of the Charter in Finland, 3th Monitoring Cycle. ECRML (2007) 7. Online 
http://www.coe.int/t/dg4/education/minlang/Report/EvaluationReports/Finlan dECRML3_en.pdf

Council of Europe (2010) Advisory Committee on the Framework Convention for the Protection of National Minorities. Third Opinion on Finland. ACFC/OP/III(2010)007. Online at http://www.coe.int/t/dghl/monitoring/minorities/3_FCNMdocs/PDF_3rd_OP_Fi nland_en.pdf

Council of Europe (2011) Report of the Committee of Experts on the Charter. Application of the Charter in Finland, 4th Monitoring Cycle. ECRML (2012) 1. Online http://www.coe.int/t/dg4/education/minlang/Report/EvaluationReports/Finlan dECRML4_en.pdf

Ethnologue. Statistical summaries. Accessed 12 January 2013. http://www.ethnologue.com/ethno_docs/distribution.asp?by=size

ETNO (2002) Suomen venäjänkielisen väestönosan kysymyksiä. Etnisten suhteiden neuvottelukunnan asettaman työryhmän raportti. Helsinki: Venäjän ja ItäEuroopan instituutti. Online at http://www.mol.fi/mol/fi/99_pdf/fi/04_maahanmuutto/04_yhdenvert/ETNO/ve najankieliset.pdf

FPCRF $=$ The Foreign Policy Concept of the Russian Federation, 2008. Online at http://archive.kremlin.ru/eng/text/docs/2008/07/204750.shtml

Gerasimov, I., Glebov, S., Kusber, J., Mogilner, M. and Semyonov, A. (2009) New imperial history and the challenges of empire. In I. Gerasimov, J. Kusber and A. Semyonov (eds) Empire Speaks Out: Languages of Rationalization and Self-description in the Russian Empire (pp. 3-32). Leiden, Boston: Brill.

Government of Finland (1999a) Initial Report of the Government of Finland on the Application of the European Charter for Regional or Minority Languages. MINLANG/PR

4.

Online at http://www.coe.int/t/dg4/education/minlang/Report/PeriodicalReports/Finlan dPR1_en.pdf

Government of Finland (1999b) Report Submitted by Finland Pursuant to Article 25, Paragraph 1 of the Framework Convention for the Protection of National Minorities. ACFC/SR(1999)003. Online at http://www.coe.int/t/dghl/monitoring/minorities/3_FCNMdocs/PDF_1st_SR_Finl and_en.pdf

Government of Finland (2002) The Second Periodic Report of Finland on the Application of the European Charter for Regional or Minority Languages. MINLANG/PR (2003) 2 2. Online at http://www.coe.int/t/dg4/education/minlang/Report/PeriodicalReports/Finlan dPR2_en.pdf

Government of Finland (2006) The Third Periodic Report of Finland on the Application of the European Charter for Regional or Minority Languages. MIN-LANG/PR (2006) $1 . \quad$ Online at http://www.coe.int/t/dg4/education/minlang/Report/PeriodicalReports/Finlan dPR3_en.pdf

Government of Finland (2010a) The Fourth Periodic Report of Finland on the Application of the European Charter for Regional or Minority Languages. Online at http://www.coe.int/t/dg4/education/minlang/Report/PeriodicalReports/Finlan dPR4_en.pdf 
Government of Finland (2010b) Third Periodic Report on the Implementation of the Framework Convention on the Protection of National Minorities. Finland. ACFC/SR/III(2010)001. Online

at http://www.coe.int/t/dghl/monitoring/minorities/3_FCNMdocs/PDF_3rd_SR_Fin land_en.pdf

Hannikainen, L. (2002) The Russian-speaking and Ethnic Russian Minority in Finland in the Light of Finland's International Obligations. In Finnish Yearbook of International Law XI, 2000 (pp. 471-486). Kluwer Law International.

Heller, M. (2008) Language and the nation-State: Challenges to sociolinguistic theory and practice. Journal of Sociolinguistics 12(4), 504-524.

Heller, M. (2011) Paths to Post-Nationalism. A Critical Ethnography of Language Identity. Oxford: Oxford University Press.

Hirsch, F. (2005) Empire of Nations: Ethnographic Knowledge and the Making of the Soviet Union. Ithaca \& London: Cornell University Press.

Hobsbawm, E. (1990) Nations and Nationalism since 1780: Programme, Myth, Reality. Cambridge: Cambridge University Press.

Ihalainen, P., Saarinen, T., Nikula, T., and Pöyhönen, S. (2011) Aika kielipolitiikassa. Päivälehtien nettikeskustelujen historiakäsitysten analyysi. [Time in the politics of language. An analysis of the conceptions of history in the Internet discussion fora in Finnish newspapers.] Kasvatus \& Aika 3, 1797-2299. http://www.kasvatus-jaaika.fi/dokumentit/aika_kielipolitiikassapaivalehtien_nettikeskustelujen_historiak asitysten_analyysi_3009111039.pdf

Jussila, O. (2004) Suomen suuriruhtinaskunta 1809-1917. Helsinki: WSOY.

Laitin, D. (1998) Identity in Formation: The Russian-Speaking Populations in the New Abroad. Ithaca \& London: Cornell University Press.

Leppänen, S. and Pahta, P. (2012) Finnish culture and language endangered? Language ideological debates on English in Finnish Press from 1995 to 2007. In J. Blommaert, S. Leppänen, P. Pahta and T. Räisänen (eds). Dangerous Multilingualism: Northern Perspectives on Order, Purity and Normality (pp. 142175). Houndsmills: Palgrave Macmillan.

Lähteenmäki, M. and Vanhala-Aniszewski, M. (2010) Introduction. In M. Lähteenmäki and M. Vanhala-Aniszewski (eds) Language Ideologies in Transition: Multilingualism in Russia and Finland (pp. 9-14). Frankfurt am Main: Peter Lang.

Lähteenmäki, M. and Vanhala-Aniszewski, M. (2012) Hard currency or a stigma: The Russian-Finnish bilingualism among young Russian-speaking immigrants in Finland. In J. Blommaert, S. Leppänen, P. Pahta and T. Räisänen (eds). Dangerous Multilingualism: Northern Perspectives on Order, Purity and Normality (pp. 121141). Houndsmills: Palgrave Macmillan.

May, S. (2001) Language and Minority Rights: Ethnicity, Nationalism and the Politics of Language. Harlow: Longman.

MIDRF $=0$ situatsii $\mathrm{s}$ pravami cheloveka $\mathrm{v}$ riade gosudarstv mira. Online at http://www.mid.ru/bdomp/brp_4.nsf/9f9f2a6497b5822f43256a2900463456/2b 4694cd44b6411e44257974003e49c4/\$FILE/\%D0\%94\%D0\%BE\%D0\%BA\%D0\% BB\%D0\%B0\%D0\%B4.pdf

Niemi, H. (2007) Russian Immigrants in Finnish Society. Soctag. Accessed 8 April 2009. http://www.socmag.net/?p=270

Pavlenko, A. (2008) (ed) Multilingualism in Post-Soviet Countries. Clevedon, UK: Multilingual Matters. 
Pyykkö, R. (2010) Language policy as a means of integration in Russia. In M. Lähteenmäki and M. Vanhala-Aniszewski (eds) Language Ideologies in Transition: Multilingualism in Russia and Finland (pp. 81-100). Frankfurt am Main: Peter Lang.

RMF = Russkiy Mir Foundation. http://www.russkiymir.ru/russkiymir/en/fund/about

Rynkänen, T. and Pöyhönen, S. (2010) Russian-speaking young immigrants in Finland: Educational and linguistic challenges to integration. In M. Lähteenmäki and M. Vanhala-Aniszewski (eds) Multilingualism in Finland and Russia. Language Ideologies in Transition (pp. 175-194). Frankfurt am Main: Peter Lang.

Smyth. S. (forthcoming) Introduction. In C. Opitz and S. Smyth (eds) Negotiating Linguistic, Cultural and Social Identities in the Post-Soviet World. Frankfurt am Main: Peter Lang.

Suny, R.G. (2001) The empire strikes out: Imperial Russia, 'national' identity, and theories of empire. In R.G. Suny and T. Martin (eds) A State of Nations: Empire and Nation-Making in the Age of Lenin and Stalin (pp. 23-66 ). Oxford, New York: Oxford University Press.

Tanttu. J. (2008) Venäjänkielisenä Suomessa. Helsinki.

Tarkiainen, K. (1986) Se vanha vainooja: käsitykset itäisestä naapurista Iivana Julmasta Pietari Suureen. Helsinki: Suomen historiallinen seura.

Vilkuna, K.H.J. (2006) Paholaisen sota. Helsinki: Teos.

Wright, S. (2007) The right to speak one's own language: Reflections on theory and practice. Language Policy 6, 203-224.

Zetterberg, S. (2005 [2001]) Main outlines of Finnish history. Virtual Finland. Accessed 18 February 2009. http://finland.fi/netcomm/news/showarticle.asp?intNWSAID=25909

ZGIaRF = Zakon 'O gosudarstvennom iazyke Rossiiskoi Federatsii', 2005. Online at http://constitution.garant.ru/act/right/12140387/ 